\title{
Managing nematodes in Egyptian citrus orchards
}

\author{
Mahfouz M. M. Abd-Elgawad
}

\begin{abstract}
Backed by its Mediterranean climate, fertile soils, cheap labor, and geographic location, Egypt ranks high among citrus producer countries. These factors can collectively offer early fruiting and long harvest season, good quality, low production costs, and closeness of export markets. However, citrus trees are attacked by many plant-parasitic nematode species in Egypt and abroad; all but one, the citrus nematode Tylenchulus semipenetrans, of which are of limited distribution. Tylenchulus semipenetrans impacts the size and quality of citrus yields differently under various conditions, but guidelines have been published to help interpret soil sample results. Other species such as migratory endoparasites (lesion nematodes), sedentary endoparasites (root-knot nematodes), and several species of ectoparasitic nematodes (spiral and stunt nematodes) can damage citrus in Egypt. Yet, due to their limited distribution and very low population densities in citrus orchards, their damaging level is uncertain or not believed to cause significant damage of citrus yield. Clearly, T. semipenetrans interacts differently with other plant pathogens often found in citrus rhizosphere. While its infection to citrus seedlings can reduce subsequent infection of roots by Phytophthora nicotianae, it can increase the virulence of Fusarium solani. Therefore, issues closely connected with citrus yield losses are presented herein. Perspectives for management of nematodes associated with citrus in Egypt were discussed in the light of their economic importance, sampling accuracy, phytosanitary measures, ecology, and biology. Cultural practices should tackle other citrus problems before managing these nematodes.
\end{abstract}

Keywords: Citrus, Nematode management, Pests and pathogens, Yield loss

\section{Introduction}

Cheap labor, geographic location, Mediterranean climate, and fertile soils have granted Egypt a high rank among citrus producer countries (Abd-Elgawad et al. 2016). It is expected (Omar and Tate 2018) that Egypt will remain the first or the second largest exporter of fresh oranges in the world and the sixth largest orange producer (Fig. 1). Moreover, the ongoing nature of the economic crisis has been enhancing the socioeconomic importance of citrus; citriculture provides a significant source of foreign currency in parallel to citrus local consumption as fresh fruit and juice. Citriculture alleviates the striking problem of unemployment in Egypt. Many orchards-owning families join to work due to the frequently small orchard size in Egypt and

Correspondence: mahfouzian2000@yahoo.com

Plant Pathology Department, National Research Centre, Dokki, Giza 12622, Egypt labor-intensive nature of citriculture. So, there is a continuous expansion in citriculture to newly reclaimed areas of Egypt. For example, in 2018/2019, Foreign Agricultural Service (FAS) in Cairo, related to the United States Department of Agriculture (USDA), forecast total planted area in oranges at 162,000 ha, a $5.1 \%$ increase from the previous year (Omar and Tate 2018). The increase in planted area is attributed to increased demand for the Egyptian citrus in the local and international markets. This increase also contributes to solve the present pressing problem of overpopulation by resettling people in such new areas.

Yet, the expansion via wide desert reclaimed land entails the danger of growing citrus seedlings infected with plant-parasitic nematodes (PPNs) especially the citrus nematode (Tylenchulus semipenetrans). The implication is that citrus growth and yield is threatened by the nematodes which invade the newly planted area via infected seedlings, organic fertilizers, plant materials, irrigation,
Springer Open

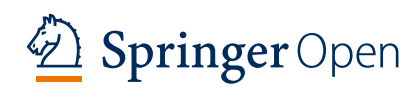

(c) The Author(s). 2020 Open Access This article is licensed under a Creative Commons Attribution 4.0 International License, which permits use, sharing, adaptation, distribution and reproduction in any medium or format, as long as you give appropriate credit to the original author(s) and the source, provide a link to the Creative Commons licence, and indicate if changes were made. The images or other third party material in this article are included in the article's Creative Commons licence, unless indicated otherwise in a credit line to the material. If material is not included in the article's Creative Commons licence and your intended use is not permitted by statutory regulation or exceeds the permitted use, you will need to obtain permission directly from the copyright holder. To view a copy of this licence, visit http://creativecommons.org/licenses/by/4.0/. 


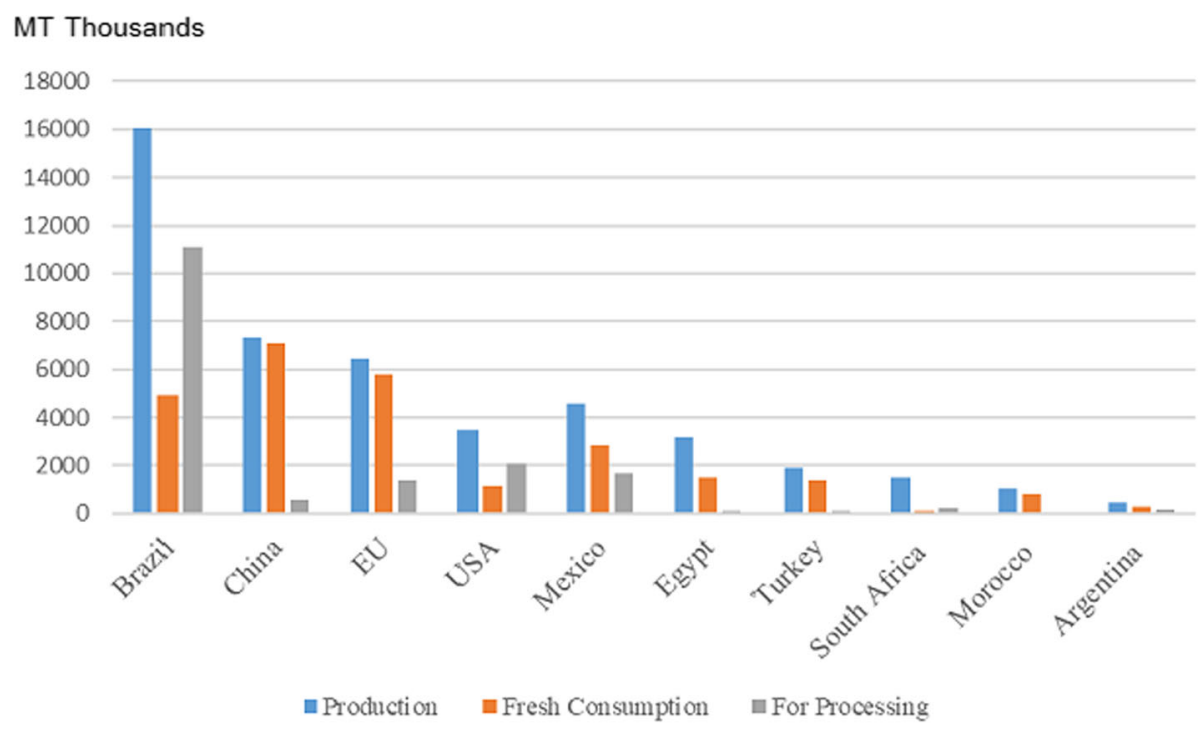

Fig. 1 World's largest orange producer countries in 2017/18 (Omar and Tate 2018)

and machinery (Abd-Elgawad et al. 2016). Also, mulching virgin soil with fertile, but probably nematodeinfested, silty soil from the Nile Valley, to improve the soil quality, before planting possible infested material may aggravate the infection (Abd-Elgawad and McSorley 2009). Over time, the nematode populations develop and reproduce rapidly and progressive increases in citrus yield losses are assumed (Abd-Elgawad et al. 2016).

Numerous citrus varieties are cultivated in Egypt. Washington Navel and Valencia orange are the main varieties related to Citrus sinensis followed by Mandarins group varieties (C. reticulata), lemon (C. aurantifolia), and Balady orange (C. sinensis), while other varieties like Grapefruit $(C . \times$ paradisi), Sour orange (C. aurantium), and Kumquat (C. japonica) are cultivated in small areas (Abobatta 2019). In parallel, many PPN species are associated with their tree rhizosphere since these varieties are mostly grafted on nematode-susceptible rootstocks in Egypt especially sour orange Citrus aurantum (ElMohamedy et al. 2016) and Volkamer lime C. volkamerina (Hammam et al. 2016a). Few PPN species, however, have proved to be of economic importance. Except Tylenchulus semipenetrans, PPNs known to be capable of damaging citrus are very limited in distribution in Egypt (Abd-Elgawad, 1992a, b; Korayem and Hassabo 2005; Abd-Elgawad et al. 2016) and elsewhere (Duncan 2009; Shokoohi and Duncan 2018). This is due either to edaphic conditions or to the natural distribution of a particular PPN species. Thus, the relationships between citrus trees and several of these species are not documented in terms of their importance and/or pathogenicity. Although regional or local in scope, nematode parasites of citrus are varied in their habitats (Duncan 2009). Migratory endoparasites (lesion and burrowing nematodes), sedentary endoparasites (citrus and rootknot nematodes), and several species of ectoparasitic nematodes can damage citrus under certain conditions. Other PPN species associated with the citrus rhizosphere lack information to set their pathogenic potential.

The present review will address the most important nematode pests that cause losses in the citrus crop in Egypt and their management. Needless to remind that there are other biotic and abiotic factors that may cause additional losses. The most important abiotic factors in Egypt are bad weather conditions, such as relatively high temperatures and severe winds during flowering and early fruit set that cause flowers and small fruits to dramatically fall. This might happen during February to June. As for biotic stresses, Citrus tristeza virus, Citrus psorosis virus, Phytophthora, Fusarium, and T. semipenetrans are the most important in Egypt. Therefore, agricultural practices should typically tackle all yieldreducing factors which would benefit sustainability evaluation in citriculture. Although the magnitude of nematode damage to any crop is related to PPN species, densities, and favoring conditions, there is consensus on the supreme importance of $T$. semipenetrans relative to other PPNs on citrus in Egypt (Abd-Elgawad, 1992a, b; Korayem and Hassabo 2005; Hammam et al. 2016b; Abd-Elgawad et al. 2016). This review throws light on the significance of the citrus nematode and provides a way forward for updated control tactics of the most common and damaging nematodes associated with citrus trees as well as general management strategies to maximize citrus yield and quality in Egypt. 


\section{PPNs of citrus in Egypt}

\section{The citrus nematode (Tylenchulus semipenetrans)}

It is a parasite of many plant species since more than 75 rutaceous species (especially citrus and their close relatives) are suitable hosts (Duncan 2009). Moreover, a few non-rutaceous hosts such as olive, grape, lilac, and persimmon are also infected. This nematode constituted 81.2\% (Abd-Elgawad, 1992a, b) and 99.1\% (Abd-Elgawad et al. 2016) of the total nematode community in surveys targeting two areas famous for citriculture in Egypt. In contrast, foreign surveys found that $T$. semipenetrans infested $24-60 \%$ in Florida and California (USA) to 7090\% in Brazil and Spain (Shokoohi and Duncan 2018) of commercial orchards. Such common infestations worldwide inform that it can damage citrus yield under a wide range of environmental and edaphic conditions. Slow decline disease of citrus is caused by this nematode where gradual tree debilitation is noticed. Aboveground symptoms of the disease are similar to those resulting from lack of nutrition, poor root development, or drought. Moreover, citrus trees can usually support very high $T$. semipenetrans population levels before damage becomes clear. Leaves and fruit are smaller and chlorosis may be evident (Philis 1989; McClure and Schmitt 1996). Symptom development depends on overall orchard conditions. Root hairs are less abundant resulting in wilting especially during periods of water stress and leaf drop is more pronounced causing thinner tree canopies in heavily infested trees. Infected trees growing under otherwise optimum conditions may yield somewhat less fruit while looking quite healthy (Duncan 2009). Under unfavorable conditions for tree growth, the $T$. semipenetrans effects are quite apparent; leaf drop is more pronounced, producing exposed branch terminals (twig dieback). In saline conditions, excessive sodium accumulates in leaves (Mashela and Nthangeni 2002). Feeder roots are somewhat thicker than healthy ones with a dirty look due to adhering soil particles to gelatinous nematode-egg masses on the surface of severely infected roots. On the contrary, such symptoms may not be evident on root systems with light T. semipenetrans infections. Unfortunately, infected nursery seedlings may easily go undetected in such cases (Shokoohi and Duncan 2018). Infected roots decay faster leading to invasion by secondary organisms (Hamid et al. 1988). This may appear as root lesions in light infection, but severe infections lead to cortical sloughing and root death. Nematode infection enhances levels of the celldamaging enzymes (Abd-Elgawad et al. 2015).

The T. semipenetrans biology and ecology have been extensively studied (Shokoohi and Duncan 2018). The egg hatches to filiform second stage juvenile $\left(\mathrm{J}_{2}\right)$ which does not immediately penetrate the roots. The nematode is sexually dimorphic with males having the ability mature to the filiform adults without feeding. The female juveniles can survive more than 2 years in the absence of roots (Duncan 2009). Amphimictic females can produce male and female offspring in the absence of males. Female $\mathrm{J}_{2} \mathrm{~s}$ feed for up to 2 weeks on epidermal cells before molting in approximately 7 days to the third, fourth, and adult stages. The anterior of young adult females penetrate deep into the fibrous root cortex to initiate a permanent feeding site at which time the females become increasingly swollen (Cohn 1964). These females feed routinely from several nurse cells that surround the nematode heads while their posteriors stay exposed on the roots. About 6 weeks after hatching at $25^{\circ} \mathrm{C}$, females lay eggs on the root surface in a gelatinous egg mass secreted from the excretory pore.

Duncan (2009) speculated an intimate coevolution of $T$. semipenetrans with citrus and other deep-rooted trees since this parasite is able to induce an intricate series of nurse cells in the cortex of the host species. Nutrients are frequently conveyed to the nematode via nurse cells with slight damage to the host. Consequently, this host can support large T. semipenetrans numbers for years. The nematode population levels may be affected differently in response to various edaphic and environmental factors such as temperature, soil moisture, and natural enemies. Depending on the region and these factors, one (Sorribas et al. 2000), two (Salem 1980), or three (Abd-Elgawad et al. 1994) distinct periods of active population development per year are recorded, but no seasonality was also found (Cohn 1966). The best $T$. semipenetrans development occurred at $25{ }^{\circ} \mathrm{C}$ with slower rates as temperatures approached upper $\left(31{ }^{\circ} \mathrm{C}\right)$ and lower $\left(20{ }^{\circ} \mathrm{C}\right)$ limits for population growth (O’Bannon et al. 1966). High summer soil temperatures may be associated with seasonally low populations in Egypt (Salem 1980). Reynolds and O'Bannon (1963) thought that T. semipenetrans population level was minimal on young trees in Arizona and Florida until the canopies developed enough to provide shade and reduce soil temperature. The nematode has little capacity for desiccation survival compared to many PPNs that must routinely survive soil drying cycles in a state of anhydrobiosis (Tsai and Van Gundy 1988). So, if the degree of soil drought causes the tree wilting, this also reduces $T$. semipenetrans population. Yet, soil moisture is often inversely related to such a population growth (Sorribas et al. 2000). Relying on whether part or all of the root system is affected by drought, the nematode populations in extremely dry parts of the rhizosphere can either grow very rapidly or decline precipitously (Duncan 2009). The T. semipenetrans population densities were higher under drip than under flood irrigation (Sorribas et al. 2000). Likewise, the population fluctuation of T. semipenetrans is regulated by seasonality in the growth of citrus organs and the availability of nutrients in roots. New and seasonal roots are favorable for nematode penetration, development, and reproduction. 
Heavy infection can kill and decay considerable feeder root masses. Thus, lightly infected trees have more rooted mass than severely infected trees. This may lead to erratic estimation via relating yield loss to nematode numbers if new root growth is still not initiated to replace those damaged by the nematode during sampling. Salinity and $\mathrm{pH}$ of soil can affect T. semipenetrans differently (Shokoohi and Duncan 2018). The T. semipenetrans populations grow best at $\mathrm{pH}$ 6-8. So, the nematode damage to citrus is greater in mild alkaline calcareous soil than in highly acidic soils. While tree nutrition affects population levels (Mangat and Sharma 1981), the genetic variety of roots affects population growth of $T$. semipenetrans, even among rootstocks that are not considered to be resistant (O'Bannon and Hutchinson 1974).

The citrus nematode in the undisturbed citrus rhizosphere is often associated with a diverse and plentiful community of other microorganisms worldwide (Shokoohi and Duncan 2018). In Egypt, some agricultural practices such as addition of humic acid can enhance microbial activity and available nutrients in favor of citrus yield (Ennab 2016). Nevertheless, T. semipenetrans interacts with such microorganisms in inconsistent ways; apparently depending on the interacted species. While its infection to citrus seedlings can reduce subsequent infection of roots by Phytophthora nicotianae, it can increase the virulence of Fusarium solani (Shokoohi and Duncan 2018). Moreover, high population level of the nematode combined with Fusarium semitectum had synergistic effect on damaging citrus seedlings (Safdar et al. 2013).

The citrus nematode impacts citrus yields differently under various conditions and locations. Consequently, different damage thresholds accompanied with relevant guidelines have been published to help interpret soil sample results (Duncan 2009). Admittedly, loss estimates for citrus nematode vary extensively between systems and applied functions (Shokoohi and Duncan 2018). In Egypt, the economic threshold figures per $1 \mathrm{~kg}$ soil and $5 \mathrm{~g}$ roots were 13,000 and 15,000 nematodes during periods of low populations in February and August but 36000 nematodes during the peak period in March for Navel orange trees grafted on sour orange rootstock (Korayem and Hassabo, 2005). Also, the gain thresholds (the value of harvested lemon that equals the cost of $T$. semipenetrans sampling and nematicide application) in Egypt were 6.083 and 4.014 metric tons of lemon feddan ${ }^{-1}\left(=4200 \mathrm{~m}^{-2}\right)$ for cadusafos and oxamyl, respectively. Likewise, the economic thresholds (the population density of $T$. semipenetrans at which the value of the damage caused is equal to the cost of both sampling and control) were 1810 and 141 second-stage juveniles $\left(150 \mathrm{~cm}^{3} \text { soil }\right)^{-1}$. Contrary to variously defined thresholds (e.g., Ferris 1978; Sorribas et al. 2008), these thresholds were based on the combined costs of nematode sampling and control to provide an actual estimate of a budget conscious choice (Abd-Elgawad et al. 2016). In California, soil stages (juveniles/100 g soil) below 800 proved a non-damaging level, more than 1600 may respond economically to nematicide treatment, and above 3600 treatments may improve yield substantially (Garabedian et al. 1984). These T. semipenetrans population levels were recorded during the peak growth period of May-July. Yet, the $T$. semipenetrans females per g root there with counts of less than 300 , more than 700 and more than 1400 represented low, moderate, and high levels, respectively; the threshold was about 850 juveniles $/ 100 \mathrm{~cm}^{3}$ soil when nematode population levels were estimated during periods of low nematode development.

\section{Diagnosis of the citrus nematode}

Caution and experience should be combined for nematode sampling and extraction to avoid erratic results. Usually nematodes are clumped in soil and along roots. So, sample size can be reduced with the same level of accuracy by sampling during seasons of high population level and in locations of abundant feeder root for nematode feeding. Also, stratified sampling of orchards into strata of healthy and unhealthy trees may increase sample precision. However, it is logic to sample during the same season each year, preferably when peak nematode levels exist, when comparison is intended. In this respect, such roots and nematodes are more plenty under the tree canopy than at the drip-line or in rows between trees (Duncan 1986). Low-volume irrigation systems concentrate root and nematode densities even further in the wetted zones (Shokoohi and Duncan 2018).

An optimum sample size with accurate estimation of T. semipenetrans density is often costly (Abd-Elgawad 2016a, 2017). Fortunately, sampling even with low precision is mostly valuable because the majority of nematode population levels are well above or below management threshold levels (Shokoohi and Duncan 2018). On the other hand, improving optimum size of nematode samples via iteration was suggested (Abd-Elgawad 2016a). This iteration, simple on using Microsoft Excel Worksheet, is followed to find a more suitable value of the statistical variable $t$ instead of, 2, its supposed imprecise value. As a case in point, precision for population density assessments of $T$. semipenetrans on citrus in Egypt and Florida are shown (Table 1) for three different sampling plans. For each method, standard error to mean ratios and confidence intervals at three probability levels are calculated using the published Taylor Power Law parameters of these plans. The confidence bands around the means of $T$. semipenetrans numbers are generally wide for $99 \%$, 95\%, and $80 \%$ probability levels compared to Meloidogyne spp. (Abd-Elgawad 2017) probably due to the high mean of citrus nematode population used and the relatively low number of samples. Yet, Florida 
Table 1 Precision estimates for Tylenchulus semipenetrans population densities based on data derived from citrus orchards ${ }^{a}$

\begin{tabular}{|c|c|c|c|c|}
\hline Standard error to mean ratio $(E)^{\mathrm{b}}$ & $\begin{array}{l}1 / 2 \text { confidence interval } \\
\text { to mean ratio }(D)^{b}\end{array}$ & $\begin{array}{l}99 \% \text { confidence } \\
\text { interval+ }\end{array}$ & $\begin{array}{l}95 \% \text { confidence } \\
\text { interval++ }\end{array}$ & $\begin{array}{l}80 \% \text { confidence } \\
\text { interval+++ }\end{array}$ \\
\hline \multicolumn{5}{|c|}{ Taylor's power law parameters: $a=0.83, b=1.95$; in stratified random sampling, Egypt } \\
\hline 0.17 & 0.35 & $1302-3698$ & $1623-3377$ & $1945-3055^{t}$ \\
\hline 0.17 & 0.33 & $1421-3579$ & $1679-3321$ & $1963-3037^{2}$ \\
\hline \multicolumn{5}{|c|}{ Taylor's power law parameters: $a=1.175, b=1.95$; in systematic sampling, Egypt } \\
\hline $20 \%$ & $42 \%$ & 1074-3926 & $1457-3543$ & $1838-3162^{t}$ \\
\hline $20 \%$ & $39 \%$ & $1216-3784$ & $1523-3477$ & $1861-3139^{z}$ \\
\hline \multicolumn{5}{|c|}{ Taylor's power law parameters: $a=9.2, b=1.57$; in random sampling, Florida, USA } \\
\hline $13 \%$ & $26 \%$ & $1598-3402$ & $1840-3160$ & $2081-2919^{t}$ \\
\hline $13 \%$ & $25 \%$ & $1688-3312$ & $1882-3118$ & $2095-2904^{z}$ \\
\hline
\end{tabular}

${ }^{2}$ Abd-Elgawad (1992a, b) for citrus in Egypt, and Duncan et al. (1989) for citrus in Florida. Soil sample size of $100 \mathrm{~g}$ in Egypt or $100 \mathrm{~cm} 3$ in Florida $t$ and $z$ refer to using Student's $t$ value and standard normal deviate, respectively

${ }^{\mathrm{b}} E$ and $D$ values rounded up to nearest two decimals with $D$ at $95 \%$ probability

populations of the citrus nematode showed narrower confidence bands than those of stratified random. This latter in turn had limited confidence bands compared to systematic sampling method in Egypt.

Estimating yield loss is based on the relationship between either natural nematode infestation densities or nematode population levels following nematicidal application and yields. Both of them have limitations. For example, nematicides may affect not only the nematodes but also other rhizosphere organisms such as natural enemies and fungal or/and bacterial pathogens. Moreover, nematicidal application may also directly affect plant development negatively (Timmer 1977) or positively (Wheaton et al. 1985). On the other hand, edaphic factors can affect both nematode and tree to various extents. Also, this relationship is sometimes falsified and/or complicated by cyclic $T$. semipenetrans population growth, carry-over stress effects from one crop/ year to the next, the interaction between nematode and other stresses and by the capacity for vigorous trees to support (tolerate) higher population levels than trees in decline (Abd-Elgawad et al. 2016). However, several models for relating yield to nematode infestation densities proved significant citrus yield loss due to the citrus nematode. In this respect, yield loss of lemon in Egypt was estimated (Table 2) and averaged $28.7 \%(P=0.026)$. The estimation related tree yield to natural nematode infestation level. Hence, it should be noted that the disparity in yields between infected and non-infected lemon trees is due to long-term, cumulative stress. During such a long-term, other stresses such as soil-borne pathogens, poor soil drainage, salinity, drought, and nutrient deficiency can maximize the yield loss. Thus, yields may (McClure and Schmitt 1996) or may not increase in the first year following nematode control. Abd-Elgawad et al. (2016) speculated that this yield loss of lemon will result from damage T. semipenetrans has already caused at sampling (February) because fruit set in Egypt always occurs until June. This is consistent with the report by Duncan (1989) that fruit yield 5 months only after nematicide application was not affected by treatment. Sorribas et al. (2008) reported that the effect of nematicides on citrus yield will be shown after the first- (McClure and Schmitt 1996), second- (Duncan 1989), or third-year applications (Greco et al. 1993). Moreover, such an effect ranged from none to several hundred percent increase in citrus fruits from treated trees but few negative impacts were recorded. Eventually, citrus yield

Table 2 Predicted marketable fruit losses in "banzaheer" lemon (Citrus aurantifolia) at increasing citrus nematode density (AbdElgawad et al. 2016)

\begin{tabular}{|c|c|c|c|c|}
\hline Nematode population $\left(\mathrm{J}_{2} / 150 \mathrm{~cm}^{3}\right.$ soil) & Predicted fruit weight (kg/tree) & Predicted fruit loss (kg/tree) & Fruit loss (Tons/feddan) & $\%$ loss \\
\hline$\overline{0}$ & 126.529 & 0 & 0 & 0 \\
\hline 110 & 102.702 & 23.827 & 3.812 & 18.8 \\
\hline 500 & 95.027 & 31.502 & 5.040 & 24.9 \\
\hline 900 & 92.048 & 34.481 & 5.517 & 27.3 \\
\hline 1200 & 90.59 & 35.939 & 5.750 & 28.4 \\
\hline 1500 & 89.459 & 37.07 & 5.931 & 29.3 \\
\hline 2000 & 88.0 & 38.529 & 6.165 & 30.5 \\
\hline 2300 & 87.292 & 39.237 & 6.278 & 31.0 \\
\hline
\end{tabular}


often increases in response to nematicide application (Shokoohi and Duncan 2018).

\section{Other nematode parasites of citrus}

Although many PPN genera and species other than $T$. semipenetrans are found in the rhizosphere of citrus trees, currently recorded nematodes to damage citrus tend to be very limited in distribution. Generally, Ibrahim (2006) reported the following genera (with related species) from citrus orchards: the spiral nematode Helicotylenchus ( $H$. dihstera, $H$. hydrophilus, $H$. microcephalus, $H$. multicinctus, H. pseudorobustus), the sheath nematode Hemicycliophora (H. Arenaria, H. similes), the lance nematode Hoplolaimus (H. Columbus, H. galeatus, $H$. seshadrii), the needle nematode Longidorus ( $L$. africanus, $L$. alongates, $L$. gerogiensis, $L$. taniwha), the lesion nematode Pratylenchus ( $P$. brachyurus, $P$. coffeae, $P$. nreglectus, $P$. penetrans, $P$. pratensis, $P$. vulnus, $P$. zeae), the burrowing nematode Radopholus (R. similes, $R$. citri), the stubby root nematode Trichodorus (T. teres, T. christiei), the stunt nematode Tylenchorhynchus (T. besselatus, T. brassicae, T. clavicaudatus, $T$. latus, T. nothus, T. phaseoli), the dagger nematode Xiphinema ( $X$. imitator, $X$. insigne, $X$. lamberti), and the reniform nematode Rotylenchulus reniformis. For example, in Egypt PPNs found in the citrus soil and the average percentages of the total nematode community were $T$. semipenetrans (81.2\%), Helicotylenchus pseudorobustus (11.7\%), Criconemella spp. (6.5\%), Pratylenchus brachyurus (0.2\%), and Tylenchorhynchus spp. (0.4\%) in Northern Tahrir Province (Abd-Elgawad, 1992a, b). Other than T. semipenetrans (99.1\%), the genera Tylenchorhynchus, Helicotylenchus, Criconemoides, Xiphinema, and Pratylenchus accounted for $0.9 \%$ of the total nematode community in citrus groves of El-Nubaria district, El-Behera governorate (Abd-Elgawad et al. 2016). Additional genera such as Meloidogyne (root-knot nematode, RKN) and Longidorus were found in citrus orchards intercropped with tomato in the New Valley governorate (Abd-Elgawad unpublished).

Shokoohi and Duncan (2018) reported that species related to both migratory endoparasite genera (Radopholus and Pratylenchus) and sedentary endoparasites (Meloidogyne), as well as a number of species of ectoparasitic nematodes can damage citrus. Fortunately, the most dangerous nematode (i.e., the citrus race of Radopholus similis) which causes the spreading decline disease of citrus is not found in Egypt. Clearly, the presence of nematode genera/species of citrus varies by geographic region. So, it is not odd to report the pathogenicity of $R$. citri associated with declining trees in Indonesia (Machon and Bridge 1996). Following are the most common PPN species of citrus groves.

Pratylenchus Three species; i.e., P. coffeae, P. brachyurus, and $P$. vulnus can damage citrus. All are found in Egyptian citrus orchards (Ibrahim et al. 2010). The widespread $P$. coffeae is the most pathogenic (Shokoohi and Duncan 2018). Lesion nematode infection occurs mainly in the feeder roots by all motile stages that penetrate cortical tissue, but vascular tissues remain intact until invaded by secondary organisms. Pratylenchus coffeae is obligatorily amphimictic, with males feeding in the roots (Inserra et al. 2001). The current climate change toward higher temperature in Egypt may aggravate root damage by $P$. coffeae because its reproduction is highest when soil temperatures are relatively high $\left(26-30{ }^{\circ} \mathrm{C}\right)$. At such temperatures, the life cycle is completed in less than 1 month and may reach density levels as high as 10,000 nematodes/ g root (O'Bannon and Tomerlin 1969), and can survive in roots in soil for at least 4 months. This species could reduce citrus root weights by as much as half. Growth reduction of young trees in the field ranged from 49 to $80 \%$, and the numbers of Fruit during the first bearing years ranged from 3-fold to 20-fold differences between infected and non-infected trees (O'Bannon and Tomerlin 1973). Commercial rootstocks resistant to $P$. coffeae have not been identified yet.

Similar to the biology of $P$. coffeae is that of $P$. brachyurus (Duncan 2009). It is a reported pathogen of citrus seedlings in different soil types (Tomerlin and O'Bannon 1974). Yields of Valencia orange trees grafted on rough lemon were enhanced after controlling P. brachyurus with aldicarb and trees showed less frost damage in winter (Wheaton et al. 1985). The fact that $P$. vulnus has been found associated with citrus trees in Egypt (Ibrahim et al. 2010) was not recognized in some reports (Duncan 2009; Shokoohi and Duncan 2018). The species is capable of causing severe damage to citrus seedlings, but is not reported to damage mature trees (Inserra and Vovlas 1977). Biology, population growth rates, and root damage are similar to those described for P. coffeae (Duncan 2009). Based on field surveys, numerous Pratylenchus species were identified in Egyptian citrus orchards (Ibrahim et al. 2010) but little studies have been done on their pathogenicity and damage to citrus.

Meloidogyne Root knot nematodes capable of attacking citrus are very limited in distribution (Shokoohi and Duncan 2018); RKNs found in citrus orchards in Egypt were possibly reproducing on tomato which was intercropped with the citrus (Abd-Elgawad unpublished). They appear to be a problem in only a few localized regions in the world. A pathogenic RKN species (known as Asiatic pyroid citrus nematode) recorded from Taiwan and New Delhi could cause elongated galls on citrus roots (Duncan 2009). It can complete its life cycle on several citrus and other plant species. Other RKN species were reported from citrus in specific regions but the common species M. incognita, M. javanica, and M. arenaria were found infecting roots of Troyer citrange and 
sour orange, causing small galls, but without reproducing (Van Gundy et al. 1959).

Xiphinema Although many species related to this genus are reported from the citrus rhizosphere, very little research has been undertaken regarding their pathogenicity to citrus (Gozel et al. 2006). Most species of Xiphinema predominate in lighter-textured soils (Cohn 1969). In Egypt, Xiphinema rivesi was isolated from soil around the rhizosphere of citrus trees (Citrus sinensis) with poor growth appearance and low yield from EL-Nobarria, EL-Behera governorate (Handoo et al. 2015). High densities of Xiphinema brevicollum were associated with declining grapefruit trees and infected seedlings had stubby, swollen, and reduced roots in Sudan (Yassin 1974). Similarly, other Xiphinema spp. were associated with similar symptoms and declining growth of citrus trees (Shokoohi and Duncan 2018).

\section{Other plant-parasitic nematodes}

Numerous nematode species such as those related to the genera Trichodorus, Paratrichodorus, and Hemicycliophora were also isolated from citrus fields (Abou-ElNaga et al. 1984) but their importance and damage to citrus trees have not been documented yet.

\section{Management of nematodes on citrus in Egypt Primary considerations \\ Appropriate nematode sampling and extraction}

Nematode sampling and extraction are basic to nematode advisory and diagnostic services. Nematode sampling should be a pre-consideration (Abd-Elgawad 2019a). Appropriate PPN sampling time and method as well as extraction and processing technique (Abd-Elgawad 2016a; Shokoohi and Duncan 2018) are fundamental to detect and identify PPN problems through adequate collection of relevant soil and fibrous roots. The samples should be sent and examined by a relevant Diagnostic and Advisory Services such as that of Diagnostic Laboratory at the Special Unit of the National Research Centre, Dokki, Giza governorate for analyses. Wise laboratory recommendations are always based on nematode history and other stressing factors, and previous production practices at the sampled grove as well as level of nematode numbers, symptoms, and damage of the sampled species/genera. The limiting factor principle should be considered (Thomason and Caswell 1987). It denotes that trees cannot respond to nematode treatment if PPNs especially T. semipenetrans are but one among other constraints to root growth. That is because the trees damaged by soil borne-pathogens, salinity, poor drainage, frequent drought, or other problems are unlikely to respond consistently to management of just PPNs. Groves should be managed adequately in all respects, before investing in nematode control tactics. On the contrary, healthy groves with high $T$. semipenetrans population densities are those in which nematode management is most likely to be profitable (Duncan 2009). Moreover, PPNs especially $T$. semipenetrans may sometimes exacerbate damage caused by other stresses (Mashela and Nthangeni 2002). Nematode threshold numbers or at least the common importance of the detected PPN species should be considered. Such thresholds may vary from one region to another and are influenced by various biotic and abiotic factors. In Egypt, the economic thresholds of $T$. semipenetrans have been estimated in the Nile valley (Korayem and Hasabo 2005) and newly reclaimed land (AbdElgawad et al. 2016) as well as on different citrus varieties (Abd-Elgawad 1995; Abd-Elgawad et al. 2016). Due to the absence of the burrowing nematode, Radopholus similis, in Egypt, treatment for other PPN species is usually only considered when they are found in combination with $T$. semipenetrans in the same field. As mentioned above, these may include many others such as stunt (Tylenchorhynchus spp.), spiral (Helicotylenchus spp.), and ring (Criconemoides spp.) nematodes which are frequently found in samples from citrus orchards. Therefore, Abd-Elgawad and McSorley (2009) applied the positive binomial model to determine the probability of detecting a particular nematode species in a sample containing mixed species (Table 3). In this respect, Abd-Elgawad (1992b) implied the presence of Tylenchulus graminis and/or T. palustris since statistically significant differences in the numbers of citrus nematode associated with the same rootstock (Citrus aurantium), between weed-free areas and weed-infested sites were found. Such results might suggest a possible presence of sympatric Tylenchulus species; i.e., T. semipenetrans is found with either or both T. palustris and T. graminis (Fig. 2). The

Table 3 Effect of sample size on the detection of Tylenchulus semipenetrans in a mixture with both T. palustris and T. graminis (Abd-Elgawad and McSorley 2009) $^{a}$

\begin{tabular}{lll}
\hline $\begin{array}{l}\text { Number of Tylenchulus } \\
\text { spp. (sample size) }\end{array}$ & $\begin{array}{l}\text { \% Tylenchulus } \\
\text { semipenetrans } \\
\text { in the population }\end{array}$ & $\begin{array}{l}\text { Percentage of detecting } \\
\text { T. semipenetrans }\end{array}$ \\
\hline 10 & 1 & 10 \\
20 & 1 & 18 \\
30 & 1 & 26 \\
10 & 5 & 40 \\
20 & 5 & 64 \\
30 & 5 & 79 \\
10 & 10 & 65 \\
20 & 10 & 88 \\
30 & 10 & 96 \\
10 & 20 & 89 \\
20 & 20 & 99 \\
30 & 20 & $>99$
\end{tabular}

${ }^{\mathrm{a}} \mathrm{All}$ fractional values rounded up to nearest integer 


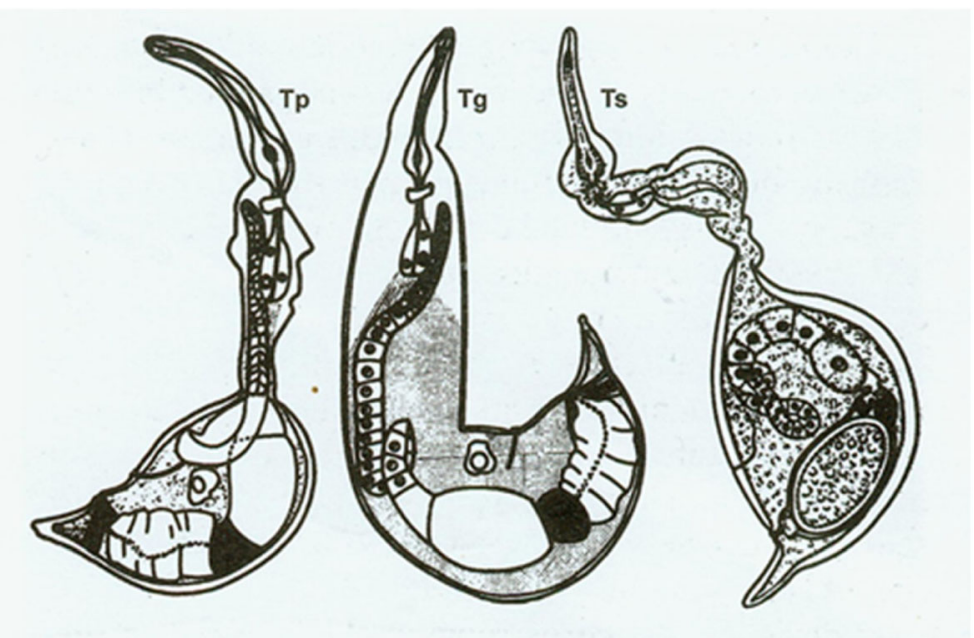

Fig. 2 Drawings of mature females. Tylenchulus palustris (Tp), T. graminis (Tg), and T. semipenetrans (Ts). Tylenchulus graminis and T. palustris parasitize native plants of Florida, whereas T. semipenetrans is a citrus parasitic species (Inserra et al. 2005)

importance of determining the effect of sample size on the detection of T. semipenetrans in a mixture with T. palustris and T. graminis (Table 3) stems from the fact that neither T. palustris nor T. graminis parasitizes citrus (Inserra et al. 1988, 2005). The former species attacks non-rutaceous dicots but the latter feeds only on monocots such as broomsedge and other grassesince. Thus, of the three species, only T. semipenetrans is a quarantine nematode. Generally, Table 3 gives probability model for detecting any species based on its prevalence in a polyspecific nematode population; a case often found in Egyptian citrus orchards (e.g., Abd-Elgawad, 1992a, b; Abd-Elgawad et al. 2016). In other words, probability of detecting $T$. semipenetrans may be applied to any mixtures of other nematode species. Yet, the exact damage to citrus yield, if any, is still restricted to a few nematode species. In this respect, minimum numbers of the lesion nematode (Pratylenchus spp.) per 100 $\mathrm{cm}^{3}$ of soil at which the crop is at risk of nematode damage is ten nematodes as given by nematode extension service, University of Florida, USA (Abd-Elgawad and Askary 2015). Nevertheless, due to their limited distribution and very low population densities, same as other PPN species except T. semipenetrans in citrus orchards, Pratylenchus spp. damaging level is uncertain or not believed to cause significant damage of citrus yield in Egypt. Fortunately, the most serious PPN species of citrus, Radopholus similis, has not been found in Egypt. Generally, other PPN population levels may affect citrus yields differently under various conditions.

Accumulated experience and advances in nematode sampling, extraction processes, and counting (e.g., Been and Schomaker 2013; Abd-Elgawad 2016b; Abd-Elgawad 2017; Shokoohi and Duncan 2018; Abd-Elgawad 2019b) have opened new avenues for further optimization of sampling size and reduced costs. Since T. semipenetrans populations are clumped in soil and along roots, sampling during seasons of peak population and in locations of highest feeder roots and nematode concentration can reduce sample size. Abundance of T. semipenetrans populations are found beneath the tree canopy than in rows between trees. For comparative purposes, it is better to sample during the season with peak population each year. Stratified random samples for areas of healthy and unhealthy trees may also improve sample precision. Irrigation system should be considered during sampling since it influences root distribution and consequently nematode spread. For a given sample size, sample precision for root stages of the nematode is less than that for soil stages. Nevertheless, reports on sample size proved that accurate estimation of $T$. semipenetrans population density is still rather costly (Duncan 2009). Hence, Abd-Elgawad (2016a) rearranged Taylor Power Law formulae to solve for the ratio of the half-width of the confidence interval to the mean of the nematode numbers rather than sample size in order to present different levels of sampling accuracy. Such levels of accuracy could be calculated which would give a primary approximation of expenditure especially in case of limited fund (Abd-Elgawad 2017). For example, different levels of accuracy are estimated along with their corresponding costs for stratified random sampling of Tylenchulus semipenetrans in citrus orchards of Egypt (Table 4). Yet, if such an accuracy level were a cause for concern, it could be minimized by collecting, recovering, and counting more samples per plot. Higher precision than the commonly used one is recommended when the economic threshold figure for the targeted nematode species lies within the confidence interval of the sample mean. Recent developments in sample collection, processing, and counting (Reid et al. 2015; Holladay 
Table 4 Percentage level of accuracy as defined in terms of the standard error to mean ratio $(E)$ and the ratio of the half-width of the confidence interval ${ }^{a}$ to the mean (D) for stratified random sampling of Tylenchulus semipenetrans in citrus orchards of Egypt (Abd-Elgawad 2017)

\begin{tabular}{llll}
\hline Cost of samples & $\begin{array}{l}\text { Finance-based } \\
\text { (US \$) }\end{array}$ & $\begin{array}{l}\text { Mean nematode } \\
\text { number of samples }\end{array}$ & $\begin{array}{l}\text { Level of } \\
\text { count per sample }\end{array}$ \\
& & $\begin{array}{ll}\text { accuracy/ } \\
\text { reliability }\end{array}$ \\
\hline
\end{tabular}

Taylor's power law parameters: $a=0.83, b=1.95$ in Egypt

\begin{tabular}{|c|c|c|c|c|}
\hline 100 & 10 & 800 & $55 \%$ & $24 \%$ \\
\hline 150 & 15 & 100 & $45 \%$ & $21 \%$ \\
\hline 150 & 15 & 1 & $50 \%$ & $24 \%$ \\
\hline 200 & 20 & 1 & $43 \%$ & $20 \%$ \\
\hline 250 & 25 & 1 & $38 \%$ & $18 \%$ \\
\hline 750 & 150 & 1 & $15 \%$ & $7 \%$ \\
\hline 200 & 20 & 2100 & $35 \%$ & $17 \%$ \\
\hline 600 & 120 & 2100 & $14 \%$ & $7 \%$ \\
\hline
\end{tabular}

et al. 2016, Abd-Elgawad 2019b) may facilitate such an adoption. In contrast, if $T$. semipenetrans population means, and consequently their confidence band, are well above or below management threshold levels, there is no matter to seek a high precision level.

As for nematode extraction, its efficiency is rarely reported, and it is often difficult to make direct comparisons between laboratories. For some soils, Baermann funnel's extraction technique appear to be similar in efficiency to techniques employing density flotation with relatively thin soil but major differences in the efficiency of the two approaches were also reported (Duncan 2009). Abd-Elgawad (1992b) estimated numbers of $T$. semipenetrans soil stages per a definite fibrous root weight because a given population density in soil may represent a different parasitic burden depending on the root mass density of the tree. Finally, atypical sampling procedures may lead to erratic results. Differences in the size or type of the sampling unit may lead to various interpretations of the resulting data (Abd-Elgawad 2019b). In essence, different sampler diameters can result in different indices of nematode distribution patterns for the same nematode population (Fig. 3). These indices should be used to normalizing the population distribution as a prerequisite to meet assumptions necessary for parametric statistical analyses. Hence, erratic results will be obtained. Therefore, standard sampling procedure is recommended for objective and more reliable comparison among PPN distribution patterns. Figure 3 shows that when an area of the sampling unit is much larger or much smaller than the average size of PPN aggregations and their clumps are regularly or randomly distributed, then their population pattern is apparently random; factual non-randomness is not detected. Nevertheless, relatively small sampler diameter can often detect non-randomness, particularly if there are not a few individuals of nematodes in each aggregation. Admittedly, sound conception of the temporal and spatial distribution of PPNs in citrus orchards is essential for their biological and ecological studies.

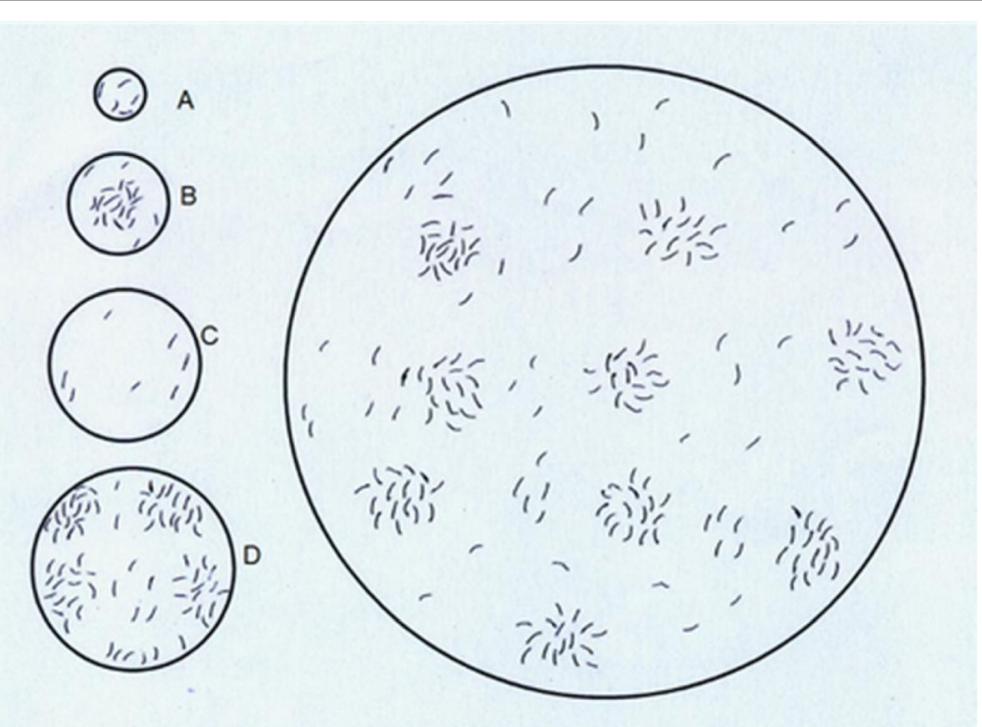

Fig. 3 Four quadrat sizes (a-d) with different distribution pattern though taken from the largest sample size which represents a contagious distribution with regularly distributed clumps of nematodes (Abd-Elgawad 2019b) 


\section{The need to improve PPN quarantine and develop certification programs}

Quarantine design and actions that have successfully achieved protection of citrus trees from citrus nematode pests in Florida (Inserra et al. 2005) should be implemented in Egypt. So, it is timely to motivate private and governmental sectors to fulfill the needs of our national certified citrus seedlings. A citrus nursery certification plan to control the nematodes particularly $T$. semipenetrans should include two basic steps of such a program; i.e., site approval and pre-movement certification of citrus plants before they go away from the nurseries. Continuous monitoring through soil sampling of nematodes is also basic to the program. Moreover, it focuses on isolating nursery locations to avoid runoff water from infested orchards and phytosanitary measures to avoid contamination of planting media and equipment in nursery area and non-infested orchards. Hence, nematode-free tools and devices for use in nurseries and non-infested orchards must be considered. Otherwise, such tools and instruments must be disinfested continually prior to their transfer to nurseries and non-infested orchards (Esser 1984). In fact, all investors and stakeholders in Egypt should address the problem collectively and, especially, allocate enough capital to produce enough certified citrus seedlings and prepare pertinent experts who can apply quarantine actions similar to those of Florida citrus. Ruefully, most citrus growers are forced to get uncertified seedlings from informal nurseries of local private markets since certified seedlings are expensive and not easily available. Limitation in distribution of certified seedlings is further aggravated by both their relatively small-scale output and the lack of awareness of citrus nematodes by many resource-poor growers. Abd-Elgawad et al. (2016) stressed that Egyptian quarantine on certifiable pathogens of citruspropagating material should also include bacteria, fungi, and other transmissible pathogens. Abd-Elgawad and McSorley (2009) also proposed a citrus nursery certification program to help overcome the reluctance of nurserymen in Egypt to move the nurseries to sites that can produce nematode-free planting material and to convince growers to refrain from mulching virgin soil with infested soil from the Nile Valley. Additionally, irrigation with some forms of running water, such as aqueducts, canals, and inland waterways, has been recognized to perform a serious source of inter-orchard contamination by both nematodes of citrus and other soil-borne pathogens especially several fungal species which can spread widely and shortly via water movement in Egypt. Cohn (1976) noted that irrigation water can be decontaminated through the use of settling ponds and filtration systems, but the procedures require skillful maintenance. In their feasibility study of such a potential program, Abd-Elgawad and McSorley (2009) found that for every L.E. 59,524 invested in a certification program, there would be a return of L.E. one million. The Florida nursery certification program saved farmers and investors US \$33 million in 1994 by decreasing citrus losses caused by the citrus nematode that would have otherwise happened via the spread of $T$. semipenetrans (Lehman 1996). Eventually, certified seedlings along with other technically qualified specifications of seedlings indicated by El-Barkoki and Abou-Aziz (1989) to ensure healthy intact-rooted plants along with the abovementioned phytosanitary measures must be a way forward in citrus protection/pest management in Egypt.

\section{Consideration of the limiting factor principle}

Firstly, the above-mentioned limiting factor principle should be addressed in Egyptian citrus groves. Still, various nematode management approaches may be included in a conclusive program of assessing all yield-forming and -reducing factors which would benefit citrus sustainability evaluation. These approaches may implement one or more of the cultural, chemical, and agronomic tactics relevant to the underlying circumstances for pest control. In addition, adequate watering to deliver irrigation rightly in terms of proper time and amount, weed control comprising hand hoeing, when necessary, integrated disease and pest management, adequate fertilization, and correct harvesting as well as pruning. This latter should help trees to grow strong and look neat as well as to remove damaged branches, allow for new growth while preparing trees for the best fruit bearing. Some Egyptian growers do it incorrectly, so they end up with damaging the tree which may aggravate the tree burden of PPN infection and/or other stressing factors. In other words, all production practices should try to minimize losses through crop management as a second step following nematode exclusion and quarantine strategy. Many Egyptian farmers have been putting some or all of these practices in effect. For example, improving soil drainage could be done via skillful irrigation system, tillage, and planting on raised beds in soils with shallow water tables. Sensitive irrigation running in order to supply water and fertilizer in accordance with the different requirements of citrus trees is necessary for each stage of the growing season particularly at the pre-bloom, bloom, and fruiting periods. Admittedly, all stressing factors that limit the productivity of citrus orchards must be tackled before controlling the PPNs. Overcoming such factors should help in and considered as indirect management of the nematodes.

\section{Nematicidal application}

Having ensured that groves are managed adequately in all respects, direct control of citrus nematode tactics should be sought. Globally, these tactics may utilize resistant rootstocks, nematicides, or production practices such as the type of the fertilizer used and solarization. 
The commercially resistant rootstock Swingle citrumelo is common in Florida and, combined with regulation program of the citrus nematode, has decreased the spread of T. semipenetrans dramatically (Lehman 1996). Even so, resistance-breaking biotypes were developed on Swingle citrumelo there (Duncan et al. 1994). Also, Swingle citrumelo proceeds poorly in Egyptian alkaline soils and those high in lime; so it is not the best target in Egypt. This does not negate that management of citrus nematode via resistant rootstocks in Egypt should draw attention toward other resistant rootstock varieties from soils similar to ours. For example, Forner-Alcaide no. 5 is a resistant rootstock variety from Spain that tolerates alkaline and calcareous soils of Egypt. It is a hybrid of Poncirus trifoliate and Cleopatra mandarin (L. Duncan, pers comm). Sorribas et al. (2003) demonstrated that trees on resistant rootstocks grew more quickly than on susceptible root-stocks in non-fumigated soil infested by $T$. semipenetrans, but not in soil fumigated with 1,3-dl-chloropropene.

Shokoohi and Duncan (2018) stressed that the most effective pre-plant nematicides in citrus are fumigants such as metam sodium and 1,3-dichloropropene. The latter fumigant has several commercial products in Egypt such as Telone II or Dorlone II, which are used in citrus nurseries/orchards for their high PPN control efficacy. Moreover, soil-borne pathogen-effective but banned methyl bromide (MB) fumigant is sometimes illegally used by some small-scale growers in Egypt due to its high control potential against nematodes and insect pests as well. In contrast, a considerable re-orientation in the sort and choice of applicable nematicides is being embraced by medium and large companies in Egypt due to environmental pollution and human health hazards of the prohibited chemicals. In this respect, the safely used chloropicrin is applied effectively against diseases but seldom nematodes or weeds. Thus, 1,3-dichloropropene is also mixed with chloropicrin (Telone C17 or Telone C35), making it a multi-purpose soil fumigant in Egypt too (Abd-Elgawad 2008). The product contains either $17 \%$ or $35 \%$ chloropicrin. Telone C35, applied in combination with a separate herbicide for weed management, was reported as the best chemical alternative replacing $\mathrm{MB}$ for achieving effective PPN control and superior strawberry production (Noling 2016; Abd-Elgawad 2019a). That is because under-canopy weed growth may reduce nematicide effectiveness (Duncan et al. 2019) in addition to sharing with the tree in its nutrition. Pre-plant fumigation of old orchard sites with histories of citrus nematode infestation can be important to prevent the rapid infection of young trees (Shokoohi and Duncan 2018). Yet, caution should be exercised to protect groundwater since pre-plant fumigants can only be used in areas with an underlying impermeable layer within $6 \mathrm{ft}$ of the soil surface capable of supporting seep irrigation (Duncan et al. 2019). Also, carful nematicidal applicators should be aware that such chemicals may generally be harmful for beneficial organisms or biological control agents (BCAs) found in the tree rhizosphere.

Production practices should focus on tackling other problems before post-plant chemical treatment to manage PPNs of citrus. Issues as improper irrigation, inferior soil drainage, poor pest and disease control, and inadequate fertilization must be solved first. For example, irrigation systems should regularly be examined prior to pesticide application to soil to prevent under- or overapplication of pesticide or water. In this respect, inferior pesticide application of chemigated nematicides could result from faulty line-end pressure valves, blocked drippers, line breaks, and/or missing emitters. However, if high population densities of nematodes were found on young trees, early management of $T$. semipenetrans populations can have a long-term positive effect on subsequent growth and productivity of the trees. Admittedly, pre-requisites for fumigation should be perfectly considered to avoid any negative results and phytotoxicity.

Post-plant, non-fumigant nematicides are usually applied in Egypt in February and March with flushing of new fibrous roots (or periods when nematodes actively invade new roots). Abd-Elgawad et al. (2016) found that the economic thresholds, which refer to nematode population level at which the value of the damage caused is equal to the cost of nematode management, were 1810 and $141 \mathrm{~T}$. semipenetrans-second-stage juveniles or $\mathrm{J}_{2}$ $\left(150 \mathrm{~cm}^{3} \text { soil }\right)^{-1}$ for cadusafos and oxamyl, respectively on lemon trees. Yet, chemical treatment to control the nematodes is generally recommended at $4000 \mathrm{~J}_{2}(250 \mathrm{~g}$ soil $^{-1}$ for fruit trees and $2400 \mathrm{~J} 2(250 \mathrm{~g} \text { soil })^{-1}$ for young trees of citrus (Anonymous 2017). Major groups of nematicides are oxime-carbamates (aldicarb, oxamyl, carbofuran) and organophosphates (fenamiphos, ethoprophos, and cadusaphos) but granular cadusafos has shown superior efficacy against $T$. semipenetrans (Verdejo-Lucas and McKenry 2014). Nevertheless, a few such as aldicarb and fenamiphos were deregistered for use in citrus whiles the efficacy and profitability of the other available nematicides vary widely (Shokoohi and Duncan 2018; El-Tanany et al. 2018). For mature citrus trees, Egyptian governmental recommendations include distribution of nematicides such as cadusaphos $10 \%$ granules at rate of $24 \mathrm{~kg} /$ Feddan on the soil surface and incorporate it mechanically into the top $10 \mathrm{~cm}$ of soil or spraying oxamyl 24\% liquid on soil surface under tree canopy and on tree shoots at rate of 41 per $600 \mathrm{l}$ water/Feddan twice; 3-4 weeks between them (Anonymous 2017). For young citrus trees, similar broadcast and incorporation of nematicides such as oxamyl $10 \%$ granules at rate of $25 \mathrm{~kg} /$ Feddan is recommended. For large-scale and commercial orchards, nematicides are applied in bands down the citrus tree rows or through low- 
volume irrigation systems. In all cases, these nematicides should be incorporated in the soil, either mechanically or with irrigation for efficacy and safety.

It is preferable to leave untreated trees as checks in order to evaluate product performance and tree growth response following nematicidal application. Moreover, splitting the maximum allowable nematicide dose for multiple applications within a season can increase efficacy markedly (Shokoohi and Duncan 2018). Such nematicides are directly lethal to PPNs and have activity against insects. Their primary action is a result of direct contact. Yet, their action is mostly due to sub-lethal effects including modification of nematode behavior, e.g., failure of males to mate with females, inhibition of egg hatch, or inability of nematodes to complete the life cycle. New compounds with nematicidal activity and different modes of action are being tested or are at the pipeline for registration (Faske and Hurd 2015; AbdElgawad and Askary, 2018, 2020). On the other hand, some systemic nematicides, such as oxamyl, are translocated within the tree and suppress both harmful and beneficial species in addition to nematodes (Hammam et al. 2016b; Shokoohi and Duncan 2018).

Since a large majority of fibrous roots grow within the surface 24-30 in of soil and decrease in abundance from the tree trunk to the row middle, proper, under-canopy, nematicide placement to maximize coverage is of great significance (Duncan et al. 2019). The under canopy placement within the surface 24-30 in of soil should best target applications to areas of highest nematode density. It is also most effective at warm soil temperature in order that nematode can develop and tree can uptake. Although adequate nematicide application rate, placement, and timing are substantial for its efficacy, repeated nematicidal application often leads to lowered efficacy due to accelerated microbial degradation. Nematicide draining to depths below the major root zone can happen rapidly due to extreme irrigation or much rainfall. Given the permeable nature of citrus sandy soils and low organic matter content especially in newly reclaimed land of Egypt, skillful irrigation schedules can foster nematode control via optimizing retention of toxic concentrations within the root zone of the trees and prevent environmental pollution.

Other agricultural practices can contribute in nematode management. Some organic and inorganic fertilizers have proved to suppress PPN populations; most nematicidal amendments are oil cakes, or animal excrements containing 2-7\% (w:w) nitrogen (RodríguezKábana 1986). In Egypt, for example, Badra and Elgindi (1979) found that ammonium nitrate, ammonium sulphate, and urea could reduce Tylenchulus semipenetrans populations in soil and roots of citrus seedlings. Solarization of soil can also be highly beneficial to the subsequent growth of cultivated crops in general (AbdElgawad et al. 2019). Also, bionematicides especially BCAs rank high among other PPN management options given mounting care to lessen application of chemical nematicides with a clear aim at the avoidance of human health hazards and attaining pollution-free environment. Nevertheless, BCAs are frequently slower acting, less effective, and more inconsistent than control normally achieved with chemicals. Abd-Elgawad (2020) has recently reviewed the different groups of BCAs to identify conditions and practices that affected their use for nematode management and alternatives to maximize their useful applications against PPNs. He reported various approaches to diminish costs, facilitate availability, optimize application, and improve their efficacy. Researchers should further grasp the complex network of interactions among biotic and abiotic factors in intimate contact with these $\mathrm{BCAs}$ to maximize their gains via safe and skillful application and advanced technology (AbdElgawad and Askary 2020). Integrated pest management programs of citrus orchards in ways that make BCAs complementary or superior to chemical nematicides should further be addressed. This is timely with the frequently reported incidence of naturally occurring communities of nematophagous fungi and parasitic bacteria such as Pasteuria species in citrus orchards (Shokoohi and Duncan 2018). Pathak et al. (2017) demonstrated habitat variation in the predominance of two of seven species of biocontrol fungi found in the DNA recovered from samples of nematodes in citrus orchards. The predator-prey model parameters for a Pasteuria sp. and $T$. semipenetrans in a citrus orchard was constructed and may be useful as a basis to design augmentation programs (Ciancio et al. 2015). Other biocontrol agents, such as predaceous mites, Pseudomonas fluorescens, Trichoderma spp., Pochonia chlamydosporia, and Purpureocillium lilacinum, with most of them available commercially (Abd-Elgawad and Askary 2018) have mostly shown potential in $T$. semipenetrans regulation (Hammam et al. 2016b; Shokoohi and Duncan 2018; El-Tanany et al. 2018; El-Saedy et al. 2019). Also, botanical extracts proved to suppress T. semipenetrans in Egypt (Amin and Youssef 2014; El-Zawahry et al. 2014).

\section{Conclusions}

The most economically important PPN species in Egypt is Tylenchulus semipenetrans due to its wide distribution in most citrus groves and population densities above the economic threshold levels. Other PPN species are found but with limited distribution and low population densities. So, their damaging level is uncertain or not believed to cause significant damage of citrus yield. Management of nematodes on citrus in Egypt requires primary considerations. These include precise and 
appropriate nematode sampling and efficient extraction, improving PPN quarantine and develop certification programs and consideration of the limiting factor principle. Nematicidal application should consider useful experience gained from previous experimentation on the citrus nematode in Egypt and worldwide. In this respect, holistic comprehension of the nematode biology and ecology as well as their reflections on the economic importance of these nematodes should be harnessed for better pest control.

\author{
Abbreviations \\ PPNs: Plant-parasitic nematodes; MB: Methyl bromide; $\mathrm{J}_{2}$ : Second-stage \\ juveniles; BCAs: Biological control agents
}

\begin{abstract}
Acknowledgement
The author acknowledges the support in part of this study by the US-Egypt Project cycle 17 (no. 172) entitled "Preparing and evaluating IPM tactics for increasing strawberry and citrus production". This article is derived from the Subject Data funded in part by NAS and USAID, and that any opinions, findings, conclusions, or recommendations expressed in it are those of the author alone, and do not necessarily reflect the views of USAID or NAS. The facilities offered by The National Research Centre are appreciated.
\end{abstract}

\section{Authors' contributions}

The author wrote, read, and approved the final manuscript.

\section{Funding}

Financial support was made by both US-Egypt Project related to Science and Technology Development Fund and National Research Centre, Egypt.

\section{Availability of data and materials}

The datasets used and/or analyzed during the current study are available from the corresponding author on reasonable request.

\section{Ethics approval and consent to participate}

Not applicable.

\section{Consent for publication}

Not applicable.

\section{Competing interests}

The author declares that he has no competing interests.

Received: 11 January 2020 Accepted: 6 March 2020

Published online: 23 March 2020

\section{References}

Abd-Elgawad MM (1992a) Spatial distribution of the phytonematode community in Egyptian citrus groves. Revue Nématol 14:367-373

Abd-Elgawad MM (1992b) Comparative occurrence of phytonematodes and yield responses of citrus. Zagazig J Agric Res 19:2293-2302

Abd-Elgawad MM (1995) Estimate of (Naval) orange yield loss in Tylenchulus semipenetrans-infested groves. Egypt J Appl Sci 10:6-14

Abd-Elgawad MMM (2008) The current status of phytonematode management in Egypt with special reference to applicable nematicides. Egypt J Agron 6:33-46

Abd-Elgawad MMM (2016a) Use of Taylor's power law parameters in nematode sampling. Int J PharmTech Res 9(12):999-1004

Abd-Elgawad MMM (2016b) Comments on the use of biocontrol agents against plant-parasitic nematodes. Int J PharmTech Res 9(12):352-359

Abd-Elgawad MMM (2017) Accuracy and precision of phytonematode sampling plans. Agric Engin Int CIGR J Special Issue:6-15

Abd-Elgawad MMM (2019a) Plant-parasitic nematodes of Strawberry in Egypt: a review. Bull. NRC 43:7. https://doi.org/10.1186/s42269-019-0049-2

Abd-Elgawad MMM (2019b) Towards optimization of entomopathogenic nematodes for more service in the biological control of insect pests. Egypt J Biol Pest Cont 29:77. https://doi.org/10.1186/s41938-019-0181-1
Abd-Elgawad MMM (2020) Plant-parasitic nematodes and their biocontrol agents: current status and future vistas. In: Ansari RA, Rizvi R, Mahmood I (eds) Management of phytonematodes: recent advances and future challenges. Springer, Germany In Press

Abd-Elgawad MMM, Abou-Deif MH, MMA MMAH, Abd-El-Khair H, FFH K, Abd ElWahab AE, Montasser SA (2015) Effect of infection with Tylenchulus semipenetrans on enzymatic activities in citrus. Int J Engineer Innov Tech 4(12):43-48

Abd-Elgawad MMM, Askary TH (2015) Impact of phytonematodes on agriculture economy. In: Askary TH, Martinelli PRP (eds) Biocontrol agents of phytonematodes. CAB International, Wallingford, pp 3-49

Abd-Elgawad MMM, Askary TH (2018) Fungal and bacterial nematicides in integrated nematode management strategies. Egypt J Biol Pest Cont 28:74 https://doi.org/10.1186/s41938-018-0080-x

Abd-Elgawad MMM, Askary TH (2020) Factors affecting success of biological agents used in controlling plant-parasitic nematodes. Egypt J Biol Pest Cont 30:17. https://doi.org/10.1186/s41938-020-00215-2

Abd-Elgawad MMM, Elshahawy IE, Abd-El-Kareem F (2019) Efficacy of soil solarization on black root rot disease and speculation on its leverage on nematodes and weeds of strawberry in Egypt. Bull. NRC 43:175. https://doi. org/10.1186/s42269-019-0236-1

Abd-Elgawad MMM, Koura FFH, Montasser SA, Hammam MMA (2016) Distribution and losses of Tylenchulus semipenetrans in citrus orchards on reclaimed land in Egypt. Nematology 18:1141-1150 http://journals. indexcopernicus.com/Egyptian+Journal+of+Agronematology,p8230,3.html

Abd-Elgawad MMM, McSorley R (2009) Movement of citrus nematode-infested material onto virgin land: detection, current status and solutions with costbenefit analysis for Egypt. Egypt J Agronematol 7(1):35-48

Abd-Elgawad MMM, Youssef MM, Shamseldean MM (1994) Observations on the population fluctuations of the citrus nematode on Calamondin orange in Egypt. Pakistan. J Nematol 12(1):87-94

Abobatta WF (2019) Citrus varieties in Egypt: An impression. Int Res J Appl Sci 1:63-66 Abou-El-Naga MM, Metwaly AM, Montasser SA (1984) New records of nematodes associated with citrus fields in Egypt. Agr Res Rev 62:271-275

Amin AW, Youssef MMA (2014) Population dynamics of the citrus nematode, Tylenchulus semipenetrans, on navel orange as affected by some plant residues, an organic manure and a biocide. Arch Phytopathol PI Protect 47(18):2233-2241

Anonymous (2017) Adopted recommendations to combat agricultural pests. Agricultural Pesticide Committee, Ministry of Agriculture, Commercial AlAhram Press, Qalioub, Qalioubia, Egypt

Badra T, Elgindi DM (1979) The relationship between phenolic content and Tylenchulus semipenetrans populations in nitrogen-amended citrus plants. Revue Nématol 2(2):161-164

Been TH, Schomaker CH (2013) Distribution patterns and sampling. In: Perry RN, Moens M (eds) Plant nematology, 2nd edn. CABI Publishing, Wallingford, pp 331-358

Ciancio A, Roccuzzo G, Ornat C (2015) Regulation of the citrus nematode Tylenchulus semipenetrans by a Pasteuria sp. endoparasite in a naturally infested soil. BioControl. https://doi.org/10.1007/s10526-015-9704-1

Cohn E (1964) Penetration of the citrus nematode in relation to root development. Nematologica 10:594-600

Cohn $E$ (1966) Observations on the survival of free-living stages of the citrus nematode. Nematologica 12:321-327

Cohn E (1969) The occurrence and distribution of species of Xiphinema and Longidorus in Israel. Nematologica 15:179-192

Cohn E (1976) Report of investigations on nematodes of citrus and subtropical fruit crops in South Africa. Citrus and Subtropical Fruit Research Institute, Nelspruit, SA: 41 pp.

Duncan LW (1986) The spatial distribution of citrus feeder roots and of the citrus nematode, Tylenchulus semipenetrans. Revue Nématol 9:233-240

Duncan LW (1989) Effect of fenamiphos placement on Tylenchulus semipenetrans and yield in a Florida citrus orchard. J Nematol 21:703-706

Duncan LW (2009) Managing nematodes in citrus orchards. In: Ciancio A, Mukerji KG (eds) Integrated management of fruit crops and forest nematodes, Springer Science+Business Media B.V., pp 135-173 https://doi.org/10.1007/ 978-1-4020-9858-1

Duncan LW, Ferguson JJ, Dunn RA, Noling JW (1989) Application of Taylor's power law to sample statistics of Tylenchulus semipenetrans in Florida citrus. Suppl J Nematol 21:707-711

Duncan LW, Inserra RN, O'Bannon JH, El-Morshedy MM (1994) Reproduction of a Florida population of Tylenchulus semipenetrans on resistant citrus rootstocks. PI Dis 78:1067-1071 
Duncan LW, Noling JW, Inserra RN (2019) 2019-2020 Florida citrus production guide: Nematodes. Entomology and Nematology Dept, Univ Florida/IFAS Extension, ENY-606, 3p

El-Barkoki MH, Abou-Aziz AB (1989) The national programme for improving citrus production. Academy of Scientific Research and Technology, Ministry of Agriculture and the National Research Centre, Cairo, Egypt

El-Mohamedy RSR, Hammam MMA, Abd-El-Kareem F, Abd-Elgawad MMM (2016) Biological soil treatment to control Fusarium solani and Tylenchulus semipenetrans on sour orange seedlings under greenhouse conditions. Int J ChemTech Res 9(7):73-85

El-Saedy MAM, Hammad SE, Awd Allah SFA (2019) Nematicidal effect of abamectin, boron, chitosan, hydrogen peroxide and Bacillus thuringiensis against citrus nematode on Valencia orange trees. J PI Sci Phytopathol 3: 111-117. https://doi.org/10.29328/journal.jpsp.1001041

El-Tanany MM, El-Shahaat MS, Khalil MS (2018) Efficacy of three bio-pesticides and oxamyl against citrus nematode (Tylenchulus semipenetrans) and on productivity of Washington Navel orange trees. Egypt J Hort 45(2):275-287

El-Zawahry AM, Mahran AMA, Sallam MA (2014) Management of citrus nematode (Tylenchulus semipenetrans) by certain plant species. J Phytopathol Pest Manage 1(3):46-52

Ennab HA (2016) Effect of humic acid on growth and productivity of Egyptian lime trees (Citrus aurantifolia swingle) under salt stress conditions. J Agric Res Kafr El-Sheikh Univ 42(4):494-505

Esser RP (1984) How nematodes enter and disperse in Florida nurseries via vehicles. Florida Department of Agriculture and Consumer Services, Division of Plant Industry, Nematol Circul 109

Faske TR, Hurd K (2015) Sensitivity of Meloidogyne incognita and Rotylenchulus reniformis to Fluopyram. J Nematol 47(4):316-321

Ferris H (1978) Nematode economic thresholds: derivation, requirements, and theoretical considerations. J Nematol 10:341-350

Garabedian S, Van Gundy SD, Mankau R, Radewald JD (1984) Nematodes. In: Integrated pest management for citrus. University of California, Riverside, pp 129-131

Gozel U, Lamberti F, Duncan L, Agostinelli A, Rosso L, Nguyen K, Adams BJ (2006) Molecular and morphological consilience in the characterisation and delimitation of five nematode species from Florida belonging to the Xiphinema americanum-group. Nematology 8:521-532

Greco N, Basile M, D'Addabbo T, Brandosino A (1993) Influence of aldicarb and fenamiphos on Tylenchulus semipenetrans population densities and orange yield. J Nematol 25:768-772

Hamid GA, Van Gundy SD, Lovatt CJ (1988) Phenologies of the citrus nematode and citrus roots treated with oxamyl. Proc Int Soc Citricult 2:993-1004

Hammam MMA, El-Mohamedy RSR, Abd-El-Kareem F, Abd-Elgawad MMM (2016a) Evaluation of soil amended with bio-agents and compost alone or in combination for controlling citrus nematode Tylenchulus semipenetrans and fusarium dry root rot on Volkamer lime under greenhouse conditions. Int J ChemTech Res 9(7):86-96

Hammam MMA, El-Nagdi WMA, Abd-Elgawad MMM (2016b) Biological and chemical control of the citrus nematode, Tylenchulus semipenetrans (Cobb, 1913) in Egypt. Egypt J Biol Pest Cont 26(2):345-349

Handoo ZA, Ibrahim IKA, Chitwood DJ, Mokbel AA (2015) First report of Xiphinema rivesi Dalmasso, 1969 on citrus in northern Egypt. Pakistan J Nematol 33(2):161-165

Holladay BH, Willett DS, Stelinski LL (2016) High throughput nematode counting with automated image processing. BioControl 61:177-183

Ibrahim IKA (2006) Diseases and pests of Fruit trees and control methods. Monshaat Al-Maarf Publisher, Alexandria, Egypt

Ibrahim IKA, Mokbel AA, Handoo ZA (2010) Current status of phytoparasitic nematodes and their host plants in Egypt. Nematropica 40:239-262

Inserra RN, Duncan LW, Troccoli A, Dunn D, Maia SosSantos J, Vovlas N (2001) Pratylenchus jaehni sp. n. from citrus in Brazil and a redescription of $P$. coffeae. Nematology 3:653-665

Inserra RN, Stanlet JD, O'Bannon JH, Esser RP (2005) Nematode quarantine and certification programmes implemented in Florida. Nematol Medit 33:113-123

Inserra RN, Vovlas N (1977) Effects of Pratylenchus vulnus on the growth of sour orange. J Nematol 9:154-157

Inserra RN, Vovlas N, O'Bannon JH, Esser RP (1988) Tylenchulus graminis n. sp. and T. palustris n. sp. (Tylenchulidae), from native flora of Florida, with notes on $T$. semipenetrans and T. furcus. J Nematol 20:266-287

Korayem AM, Hassabo SAA (2005) Citrus yield in relation to Tylenchulus semipenetrans in silty loam soil. Int J Nematol 15:179-182

Lehman PS (1996) Role of plant protection organizations in nematode management. XIX Congress of Brazilian Society of Nematology, Rio Quente, Brazil, pp 137-148
Machon JE, Bridge J (1996) Radopholus citri n. sp. (Tylenchida: Pratylenchidae) and its pathogenicity on citrus. Fundament Appl Nematol 19:127-133

Mangat BPS, Sharma NK (1981) Influence of host nutrition on multiplication and development of citrus nematode. Indian Phytopathol 34:90-91

Mashela PW, Nthangeni ME (2002) Osmolyte allocation in response to Tylenchulus semipenetrans infection, stem girdling, and root pruning in citrus. J Nematol 34:273-277

McClure MA, Schmitt ME (1996) Control of citrus nematode, Tylenchulus semipenetrans, with cadusafos. J Nematol 28:624-628

Noling JW (2016) Nematode management in strawberries, University of Florida publication Series no. ENY-031, USA, p 12

O'Bannon JH, Hutchinson DH (1974) Development of rootstocks resistant to the citrus nematode, Tylenchulus semipenetrans. In: Jackson LK, Krezdorn AH, Soule J (eds) Proceedings of the 1st International Citrus Short Course (Sept 24-29, 1973). Gainesville, Florida, pp 22-29

O'Bannon JH, Reynolds HW, Leathers CR (1966) Effects of temperature on penetration, development, and reproduction of Tylenchulus semipenetrans. Nematologica 12:483-487

O'Bannon JH, Tomerlin AT (1969) Population studies on two species of Pratylenchus on citrus. J Nematol 1:299-300

O'Bannon JH, Tomerlin AT (1973) Citrus tree decline caused by Pratylenchus coffeae. J Nematol 5:311-316

Omar S, Tate B (2018) Egypt: Citrus Annual. Gain Report Number: EG 18031, USDA Foreign Agricultural Service, 10 p. https://apps.fas.usda.gov/ newgainapi/api/report/downloadreportbyfilename?filename=Citrus\%2 OAnnual_Cairo_Egypt_12-10-2018.pdf (accessed 22 January 2020)

Pathak E, Campos-Herrera R, El-Borai FE, Duncan LW (2017) Spatial association between entomopathogenic nematodes and nematophagous fungi in Florida citrus orchards. J invert Pathol 144:37-46

Philis I (1989) Yield loss assessment caused by the citrus nematode Tylenchulus semipenetrans on Valencia oranges in Cyprus. Nematol Medit 17:5-6

Reid A, Evans F, Mulholland V, Cole Y, Pickup J (2015) High-throughput diagnosis of potato cyst nematodes in soil samples. In: Lacomme C (ed.) Plant Pathology: Techniques and Protocols, Methods in Molecular Biology, second ed. Springer Science+Business Media, New York, pp. 137-148

Reynolds HW, O'Bannon JH (1963) Factors influencing the citrus replants in Arizona. Nematologica 9:337-340

Rodríguez-Kábana R (1986) Organic and inorganic nitrogen amendments to soil as nematode suppressants. J Nematol 18(2):129-134

Safdar A, Javed N, Khan SA, Safdar H, Haq IU, Abbas H, Ullah Z (2013) Synergistic effect of a fungus, Fusarium semitectum, and a nematode, Tylenchulus semipenetrans, on citrus decline. Pakist J Zool 45(3):643-651

Salem AAM (1980) Observations on the population dynamics of the citrus nematode, Tylenchulus semipenetrans in Sharkia Governorate. Egypt J Phytopathol 12:31-34

Shokoohi E, Duncan LW (2018) Nematode parasites of citrus. In:. Sikora R, Timper $P$, Coyne D (eds) Plant-parasitic nematodes in tropical \& subtropical agriculture, 3rd Edition. CAB International, St. Albans, UK, pp 446-476

Sorribas FJ, Verdejo-Lucas S, Forner JB, Alcaide A, Pons J, Ornat C (2000) Seasonality of Tylenchulus semipenetrans Cobb and Pasteuria sp. in citrus orchards in Spain. Suppl J Nematol 32(4S):622-632

Sorribas FJ, Verdejo-Lucas S, Galeano M, Pastor J, Ornat C (2003) Effect of 1,3 dichloropropene and rootstocks alone and in combination on Tylenchulus semipenetrans and citrus tree growth in a replant management program. Nematropica 33:149-158

Sorribas FJ, Verdejo-Lucas S, Pastor J, Ornat C, Pons J, Valero J (2008) Population densities of Tylenchulus semipenetrans related to physicochemical properties of soil and yield of clementine mandarin in Spain. PI Disease 92:445-450

Thomason IJ, Caswell EP (1987) Principles of nematode control. In: Brown RH, Kerry BR (eds) Principles and practice of nematode control in crops. Academic Press, Australia, pp 87-130

Timmer LW (1977) Control of citrus nematode Tylenchulus semipenetrans on finetextured soil with DBCP and oxamyl. J Nematol 9:45-50

Tomerlin AT, O'Bannon JH (1974) Effect of Radopholus similis and Pratylenchus brachyurus on citrus seedlings in three soils. Soil Crop Sci Soc Florida Proc 33:95-97

Tsai BY, Van Gundy SD (1988) Comparison of anhydrobiotic ability of the citrus nematode with other plant parasitic nematodes. Proc Int Soc Citricult 2: 983-992

Van Gundy SD, Thomason IJ, Rackham RL (1959) The reaction of three Citrus spp. to three Meloidogyne spp. PI Disease Rep 43:970-971

Verdejo-Lucas S, McKenry MV (2014) Management of the citrus nematode, Tylenchulus semipenetrans. J Nematol 36(4):424-432 
Wheaton TA, Childers CC, Timmer LW, Duncan LW, Nikdel S (1985) Effects of aldicarb on yield, fruit quality, and tree condition on Florida citrus. Proc Florida State Hort Soc 98:6-10

Yassin AM (1974) A note on Longidorus and Xiphinema species from the Sudan. Nematol Medit 2:141-147

\section{Publisher's Note}

Springer Nature remains neutral with regard to jurisdictional claims in published maps and institutional affiliations.

\section{Submit your manuscript to a SpringerOpen ${ }^{\ominus}$} journal and benefit from:

- Convenient online submission

- Rigorous peer review

- Open access: articles freely available online

- High visibility within the field

- Retaining the copyright to your article

Submit your next manuscript at $\boldsymbol{\nabla}$ springeropen.com 